\title{
Studies on Cross-linking of Succinic Acid with Chitosan/Collagen
}

\author{
Tapas Mitra, G. Sailakshmi, A. Gnanamani*, A. B. Mandal
}

\author{
Microbiology Division, Central Leather Research Institute - CSIR(New Delhi), \\ Adyar, Chennai 20, Tamil Nadu, India
}

Received: May 4, 2012; Revised: December 17, 2012

\begin{abstract}
The present study summarizes the cross-linking property of succinic acid with chitosan /collagen. In detail, the chemistry behind the cross-linking and the improvement in mechanical and thermal properties of the cross-linked material were discussed with suitable instruments and bioinformatics tools. The concentration of succinic acid with reference to the chosen polymers was optimized. A 3D scaffold prepared using an optimized concentration of succinic acid $(0.2 \%(\mathrm{w} / \mathrm{v}))$ with chitosan $(1.0 \%(\mathrm{w} / \mathrm{v}))$ and similarly with collagen $(0.5 \%(\mathrm{w} / \mathrm{v}))$, was subjected to surface morphology, FT-IR analysis, tensile strength assessment, thermal stability and biocompatibility. Results revealed, cross-linking with succinic acid impart appreciable mechanical strength to the scaffold material. In silico analysis suggested the prevalence of non-covalent interactions, which played a crucial role in improving the mechanical and thermal properties of the cross-linked scaffold. The resultant 3D scaffold may find application as wound dressing material, as an implant in clinical applications and as a tissue engineering material.
\end{abstract}

Keywords: succinic acid, chitosan, collagen, 3D scaffold

\section{Introduction}

Polymers from natural resources have received high attention in the recent past as the important material for biotechnological and biomedical application owing to their unique characteristics such as biological compatibility with natural environment, non-toxicity and biodegradability. Most of the research publications discusses the significance of chitosan and collagen in biomedical applications ${ }^{1-3}$. Collagen is known to be the most promising material and with diverse applications in tissue engineering for its excellent biocompatibility and biodegradability. Chitosan, a cationic natural polymer, widely used as a topical dressing in wound management owing to its haemostatic, stimulation of healing, antimicrobial, biocompatible and biodegradable properties. However, the fast biodegrading rate and the low mechanical strength of the unstabilized collagen and chitosan scaffolds pose crucial problems and limits the use of these materials in clinical applications. Cross-linking/stabilizing the collagen/chitosan using exogenous cross-linkers is an effective method to tune the rate of biodegradation and the mechanical property of the scaffolds. Cross-linkers such as resimene, ${ }^{4}$ epichlorohydrin, ${ }^{5}$ genipin ${ }^{6}$ and glutaraldehyde ${ }^{7}$ were reported for chitosan. Chromium, ${ }^{8}$ aldehydes, ${ }^{9}$ hexamethylene diisocyanate, ${ }^{10}$ carbodiimide, ${ }^{11}$ acylazides ${ }^{12}$ citric acid, maleic acid derivatives $^{13}$ and various other physical treatments like $\mathrm{UV}^{14}$ were reported for type-I collagen. All the above said exogenous cross-linkers, cross-linked with chitosan or with type-I collagen through; (i) covalent amide/imine linkage; (ii) metal-protein complex formation (chromium cross-linking with type-I collagen); (iii) H-bond formation (between polyphenolic - $\mathrm{OH}$ group with different type

*e-mail: gnanamani3@gmail.com of amino acids of type-I collagen molecule and amino groups of chitosan) etc. Though these cross-linking agents offered mechanical strength and stability, the release of toxic components upon usage restricted the applications. According to Leung ${ }^{15}$ and Ballantyne et al. ${ }^{16}$ dialdehyde poses toxicity to the environment. In addition, the required flexibility could not be achieved because of the covalent interactions as discussed above.

In general, mechanical property of any scaffold material depends on the interaction between the cross-linkers/stabilizers and the parent molecule (here it is chitosan and collagen of type -I). As summarized above, reports on bonding interactions of said cross-linkers suggested, only the covalent interactions predominates, which, ultimately restricts the molecule to attain the desired mechanical strength.

Thus, in order to obviate the problems associated with mechanical property and the biocompatibility of biomaterials, we attempt to cross-link the parent molecule with suitable cross-linker through non-covalent interactions. In this study we have chosen succinic acid to cross-link with natural polymers. Succinic acid (butanedioic acid), C-2 ( $\left.\mathrm{HOOC}\left(\mathrm{CH}_{2}\right)_{2} \mathrm{COOH}\right)$ dicarboxylic acid, occurs naturally in plant and animal tissues, and soluble in water. It plays a significant role in intermediary metabolism (Krebs cycle) in the body. Succinic acid and their derivatives are used for the following applications, viz., drug, agriculture, food products and industrial uses. The reason for selecting succinic acid is because of its non-toxicity ${ }^{17}$.

Thus, the present study emphasizes, succinic acid as cross-linker for the natural polymers chitosan and type-I collagen and demonstrated the cross-linking chemistry between the molecules using suitable Bioinformatics tools. 
Further, the study also explores the thermal, mechanical properties and the biocompatibility of the resultant scaffold.

\section{Experimental Details}

\subsection{Materials}

Chitosan from shrimp shells ( $\geq 75 \%$ deacetylated), succinic acid, Picrylsulfonic acid [2, 4, 6-Trinitrobenzene sulfonic acid (TNBS)], were obtained from Sigma- Aldrich (USA). 3-[4,5-Dimethylthiazol-2-yl]-2,5dephenyltetrazolium bromide (MTT), dexamethasone was purchased from Hi- Media (India). All the other reagents were of Analytical Reagent grade and used without further purification. Type-I collagen from bovine skin was extracted according to the procedure followed by Mitra et al. ${ }^{18}$

\subsection{Fabrication of scaffolds}

The powder form of chitosan $(1 \%)$ and type-I collagen $(0.5 \%)(\mathrm{w} / \mathrm{v})$ was individually added to $20 \mathrm{~mL}$ of water in the glass beaker and stirred vigorously to ensure the uniform distribution. To that dispersed mixture, succinic acid was added and the stirring was continued for an hour. Concentration of succinic acid (SA) was varied between $0.05-0.5 \%(\mathrm{w} / \mathrm{v})$. Collagen samples were stirred at $4{ }^{\circ} \mathrm{C}$, whereas, chitosan samples were stirred at ambient temperature. Followed by stirring, the samples were subjected to centrifugation in order to remove any unreacted molecules and a clear solution obtained upon centrifugation at 5,000 RPM for 10 minutes and was poured in Tarson (India) vial of an inner diameter of $4.5 \mathrm{~cm}$ and frozen at $-4{ }^{\circ} \mathrm{C}$ for 2 hours, $-20{ }^{\circ} \mathrm{C}$ for 12 hours and $-80{ }^{\circ} \mathrm{C}$ for another 12 hours ${ }^{19}$. The frozen samples were lyophilized for $48 \mathrm{~h}$ at a vacuum of 7.5 militorr $(1 \mathrm{~Pa})$ and a condenser temperature of $-70^{\circ} \mathrm{C}$ (PENQU CLASSIC PLUS, Lark, India). The resultant 3D scaffold material was neutralized with repeated washings with $0.05 \mathrm{~N} \mathrm{NaOH} /$ ethanol mixture followed by washings with water/ethanol (7:3) mixture and finally again lyophilized for 24 hours. The scaffold obtained during this procedure was designated as SACCH (succinic acid cross-linked chitosan) and SACC (succinic acid crosslinked collagen).

For comparative analysis, glutaraldehyde cross-linked chitosan scaffold (GACCH) and glutaraldehyde cross-linked collagen scaffold (GACC) was prepared according to the method described in the above-said paragraph using $0.2 \%$ glutaraldehyde.

The morphology of the scaffolds of succinic acid cross-linked chitosan and collagen was assessed using scanning electron micrograph using F E I Quanta FEG 200 - High Resolution Scanning Electron Microscope instrument under high voltage at $20 \mathrm{kV}$.

\subsection{FT-IR analysis}

Functional group analysis (FT-IR) for SA, chitosan, type-I collagen, SACCH and SACC were made by cutting the scaffold into pieces $(1 \times 1 \mathrm{~cm})$ and placed in the sample compartment and analyzed using spectrum one (Perkin-Elmer Co., USA model). All spectra were recorded with the resolution of $4 \mathrm{~cm}^{-1}$ in the range of $400-4000 \mathrm{~cm}^{-1}$ with 20 scans.

\subsection{Cross-linking degree (TNBS assay) determination}

Degree of cross-linking was quantified by TNBS assay according to the procedure summarized by Bubnis et al. ${ }^{20}$. In brief, native and cross-linked (SACCH and SACC) scaffold materials were cut into small pieces of size $4.5 \mathrm{~mm}$. Six milligrams of cut pieces were immersed in a $2 \mathrm{~mL}$ solution [1 $\mathrm{mL}$ of $4 \%(\mathrm{w} / \mathrm{v})$ di-sodium hydrogen orthophosphate and $1 \mathrm{ml}$ of $0.5 \%$ (v/v) TNBS], and incubated at $40^{\circ} \mathrm{C}$ for 2 hours. Termination of reaction was with the addition of $3 \mathrm{~mL}$ of $6 \mathrm{M} \mathrm{(v/v)} \mathrm{HCl}$ and the incubation was continued at $60^{\circ} \mathrm{C}$ for 90 minutes. The absorbance of the resulting solution was measured at $345 \mathrm{~nm}$ and the percentage of cross-linking was calculated from the difference in the absorbance divided by the absorbance of the native material and then multiplied with 100 . The absorbance of the resulting mixture was measured at $\mathrm{A}_{345} \mathrm{~nm}$ using UV-Visible spectrophotometer.

\subsection{Mechanical properties of SACCH, SACC, GACCH and GACC scffolds}

Mechanical properties, viz., Young's modulus, ultimate tensile strength, stiffness and percentage of elongation of the dried scaffolds were measured using Universal Testing Machine (INSTRON model 1405) at a crosshead speed of $5 \mathrm{~mm} \mathrm{~min}^{-1}$ at $25{ }^{\circ} \mathrm{C}$ and $65 \%$ relative humidity. Length and width of the dumbbell shaped test samples were maintained at 20 and $5 \mathrm{~mm}$ respectively. All the mechanical tests were performed with dried samples and were examined in triplicate way.

\subsection{Thermo gravimetric analysis (TGA)}

Thermal decomposition analysis of SA, native and cross-linked scaffolds (chitosan, type-I collagen, SACCH, SACC, GACCH and GACC) were carried out under nitrogen flow $\left(40 \& 60 \mathrm{~mL} \mathrm{~min}^{-1}\right.$ ) with ramp $20{ }^{\circ} \mathrm{C} \mathrm{min}^{-1}$ using TGA Q 50(V20.6 build 31) instrument.

\subsection{Differential scanning calorimetry (DSC)}

Thermal properties of SA, native and cross-linked scaffolds (chitosan, type-I collagen, SACCH, SACC, $\mathrm{GACCH}$ and GACC) were analyzed using a differential scanning calorimeter, model -DSC Q 200(V 23.10 Build 79) with standard mode at nitrogen $\left(50 \mathrm{~mL} \mathrm{~min}^{-1}\right)$ atmosphere with ramp $10{ }^{\circ} \mathrm{C} \mathrm{min}^{-1}$.

\subsection{Docking and Binding energy calculations}

For the docking study, chemical structures of chitosan and SA were generated using ACD/ChemSketch ${ }^{21}$. The three-dimensional structure of type-I collagen was generated using gencollagen program ${ }^{22}$. Docking techniques are useful to find out the binding efficiency with ligand and a chemical compound. To find out the interaction between chitosan and type-I collagen with SA, AUTODOCK has been used and AutoDock 4.2 used to calculate ${ }^{23}$ the free energy of binding of SA with chitosan and type-I collagen. It's faster than other versions and force field includes an updated charge-based desolvation term, improvements in the directionality of hydrogen bonds, and several improved models of the unbound state. Current procedure categorized under semi-flexible docking protocol in that chitosan and type-I collagen was kept as rigid and ligands being docked were kept flexible; Kollman united atom charges, salvation parameters and polar hydrogens were added to chitosan PDB 
file for the polysaccharide, in ligands Gasteiger charges were assigned and then non polar hydrogen was merged before docking simulation. Total numbers of rigid roots were defined using automatically with amide bond kept as non-rotatable. The possible dihedral in the ligand is allowed to rotate freely using Auto-Tors. Pre-calculated grid maps for each atom in the ligand were generated using an Auto-grid. The $5 \mathrm{~A}^{\circ}$ grid was built surrounding the binding pocket. Three-dimensional grids of interaction energy for all possible atom types that were already present in the Auto Dock default parameter set were calculated. This grid maps were of dimension $60 \times 60 \times 60$ points with the spacing of $0.375 \mathrm{~A}^{\circ}$ yielding a receptor model that included atoms within $0.5 \mathrm{~A}^{\circ}$ of the grid center. The Graphical User Interface program "Auto-Dock Tools" was used to prepare, run and analyze the docking simulations. The Lamarckian Genetic Algorithm (LGA) was chosen to search for the best conformers.

\subsection{Biocompatibility of the SACCH and SACC scaffolds- an in vitro assessment}

Biocompatibility in terms of cell viability, live cell detection and cell attachment on the prepared scaffold were analyzed using NIH 3 T3 fibroblast cell line. According to Trentani et al. ${ }^{24}$ this cell line are a robust and durable platform for investigating common cellular functions: attachment, viability, proliferation and cellular properties etc. Cells were grown in DMEM (Dulbecco's modified Eagle's medium) supplemented with $10 \%$ (v/v) fetal bovine serum and $1 \%$ antibiotic and were incubated at $37^{\circ} \mathrm{C}$ in $5 \%$ $\mathrm{CO}_{2}$ humidified atmosphere. Polystyrene 96 well culture plates (Tarson, India) were coated with native chitosan, type-I collagen and SA cross-linked chitosan (SACCH) and type-I collagen (SACC) scaffold. The plates were dried under laminar air flow hood followed by UV sterilization. The cells were seeded at the density of $0.5 \times 10^{6}$ per well and incubated at $37{ }^{\circ} \mathrm{C}$ in a humidified atmosphere containing $5 \% \mathrm{CO}_{2}$. At scheduled time points of 24, 48, and 72 hours, the supernatant of each well was replaced with MTT diluted in serum-free medium, and the plates incubated at $37^{\circ} \mathrm{C}$ for 4 hours. After removing the MTT solution, acid isopropanol $(0.04 \mathrm{~N} \mathrm{HCl}$ in isopropanol) was added to each well and mixed to dissolve all the dark-blue crystals and then left at room temperature for a few minutes to ensure the dissolution of all crystals. Finally, absorbance was measured at $570 \mathrm{~nm}$ using a UV spectrophotometer ${ }^{25}$. Each experiment was performed at least three times.

Cell viability was measured using 5-chloromethylfluorescein diacetate probe (CMFDA) (Invitrogen). NIH 3T3 cells were subjected to respective treatment conditions. Cells were probed with $5 \mu \mathrm{M}$ CMFDA and incubated for 2 hours. Cells were then washed with sterile PBS and images were taken using DP71 camera adapted to an Olympus IX71 microscope ${ }^{26}$

\subsection{Cell attachment on prepared scaffold}

To assess the morphology of the cells on the SACCH \& SACC $(2 \times 2 \times 1 \mathrm{~cm})$, scaffold were placed in 6 well culture plates (Tarson, India) and ETO sterilized. Culture media were added to the scaffolds for overnight. NIH 3 T3 fibroblast cells were seeded onto the scaffolds at a density of $5 \times 10^{4}$ cells and incubated in an atmosphere of $5 \% \mathrm{CO}_{2}$ at $37{ }^{\circ} \mathrm{C}$. The medium was changed every 24 hours. The morphology of the cells was examined after 12 days. The cells-scaffold constructs were fixed in $2.5 \%$ glutaraldehyde and dehydrated through a graded ethanol series. The dried cells-scaffold were coated with gold (E-1010 Ion sputter, HITACHI) and examined under SEM (S-3400 N Scanning Electron Microscope. HITACHI).

\section{Results and Discussion}

As described in the Introduction, cross-linkers are used to stabilize natural polymer materials for biomedical applications. However, use of these materials solely depends on the mechanical strength and biocompatibility. Achieving good mechanical strength without compromising the biocompatible nature of the material is a challenging task. However, the nature of the cross-linkers and the interaction chemistry may provide scaffold materials with requisite properties. In the present study, we have chosen two natural polymers to understand the chemistry behind the interaction of the chosen cross-linker namely, succinic acid.

\subsection{Scaffold preparation using succinic acid: Understanding the cross-linking chemistry}

For the preparation of any scaffold materials, the solution form of parent compound/polymer is required to proceed further. However, in the case of chitosan and collagen, acetic and formic acids were used for dissolution ${ }^{27,28}$.

The "proton exchange" between - $\mathrm{COOH}$ groups of acid molecule and free $-\mathrm{NH}_{2}$ groups of chitosan and collagen could be the reason for the dissolution in the said acids.

Therefore, it has been expected that succinic acid also able to donate protons to dissolve chitosan and type-I collagen. Further, alike interaction of TPP (tripolyphosphate) ${ }^{29}$ with chitosan, succinic acid also interacts with both the natural polymers through ionic interaction.

Because of the said proton exchange, chitosan and type-I collagen got dissolved in the presence of succinic acid in water and the use of acetic acid was completely avoided.

With the resulting solution, scaffolds were prepared and subjected to characterization studies. Figure 1 demonstrates morphological features of the cross-linked scaffold (SACCH and SACC). The 3D scaffold material was highly porous, and the pore structures of the scaffolds were well-distributed and interconnected. It was obvious that most of the volume of the scaffold was taken up by the interconnecting pore space. The high porosity suggests the suitability of this scaffold for biomedical applications, including serving as absorption sponges and matrices for cell proliferation.

FT-IR studies were conducted to monitor the chemical modifications in chitosan and collagen structures upon interaction with SA. Figure 2 illustrates the FT-IR spectral details of succinic acid (SA), chitosan, collagen, SACCH and SACC. Table 1 demonstrates the FT-IR peak assignments of SA, chitosan and collagen. In SACCH spectrum, few significant changes were observed. A broad, strong absorption in the region of 3524-2821 cm $\mathrm{cm}^{-1}$ was resulting from superimposed $-\mathrm{OH}$ and $-\mathrm{NH}_{3}{ }^{+}$stretching band. Absorption in 1644 and $1577 \mathrm{~cm}^{-1}$ correspond to the presence of asymmetric $\mathrm{N}-\mathrm{H}\left(-\mathrm{NH}_{3}^{+}\right)$bend and asymmetric $-\mathrm{COO}^{-}$stretching respectively. Peak observed at 1500 and $1380 \mathrm{~cm}^{-1}$ was due to symmetric $\mathrm{N}-\mathrm{H}\left(-\mathrm{NH}_{3}^{+}\right)$bend and symmetric $-\mathrm{Z} 257,1157$ and $897 \mathrm{~cm}^{-1}$ observed in SACCH spectrum were similar to the native chitosan spectrum which exhibits that there was no change in the main backbone of chitosan structure. 


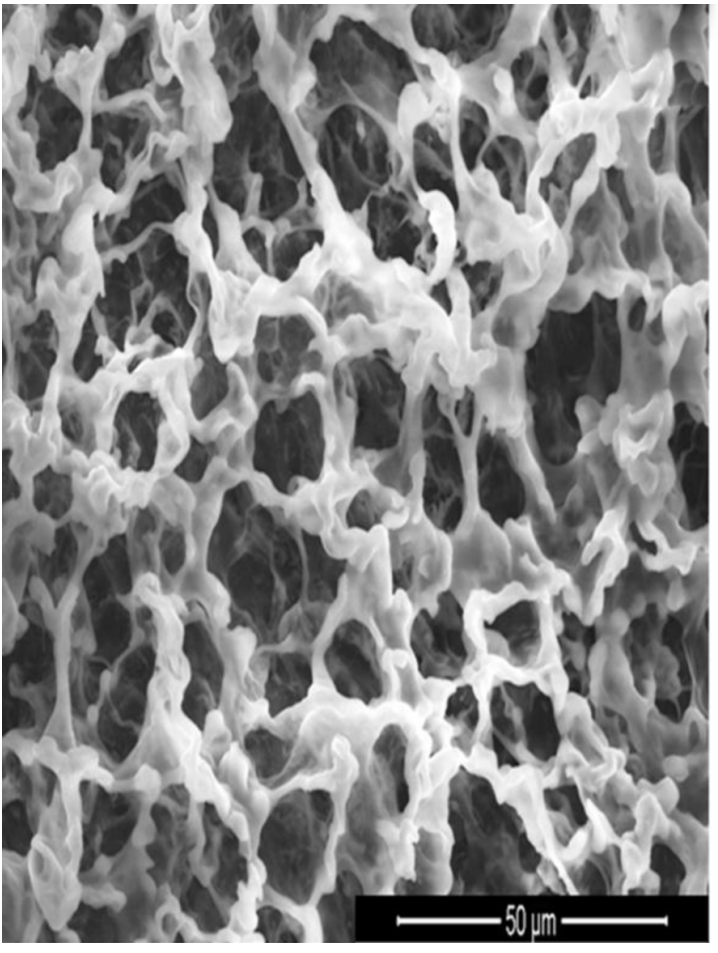

(a)

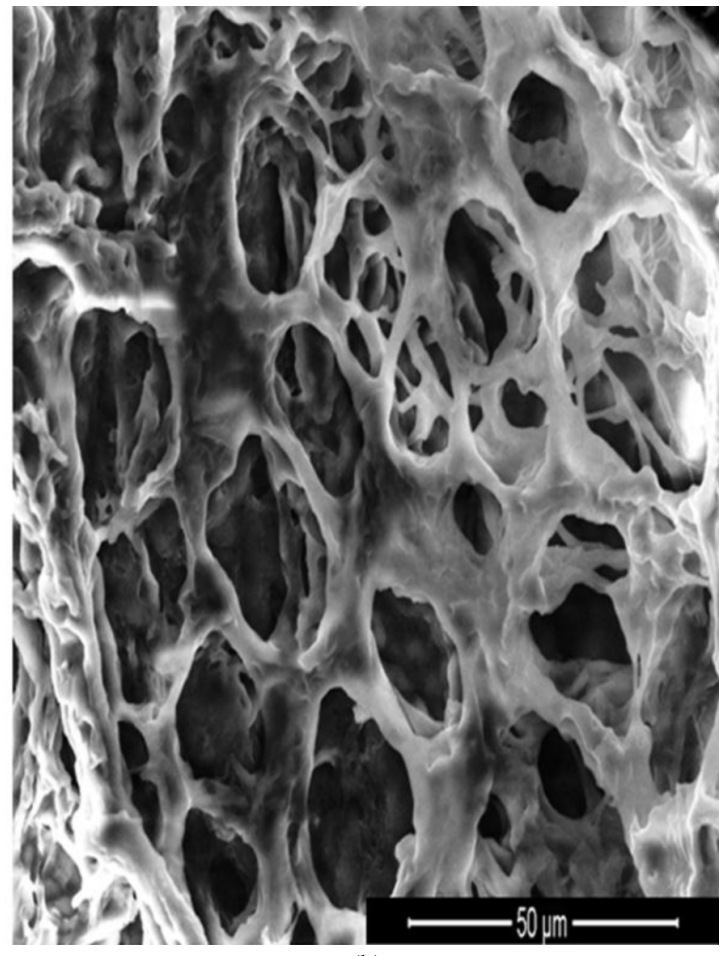

(b)

Figure 1. (a) SEM Micrographs of succinic acid cross-linked chitosan (SACCH) and (b) succinic acid cross-linked collagen (SACC) scaffolds.

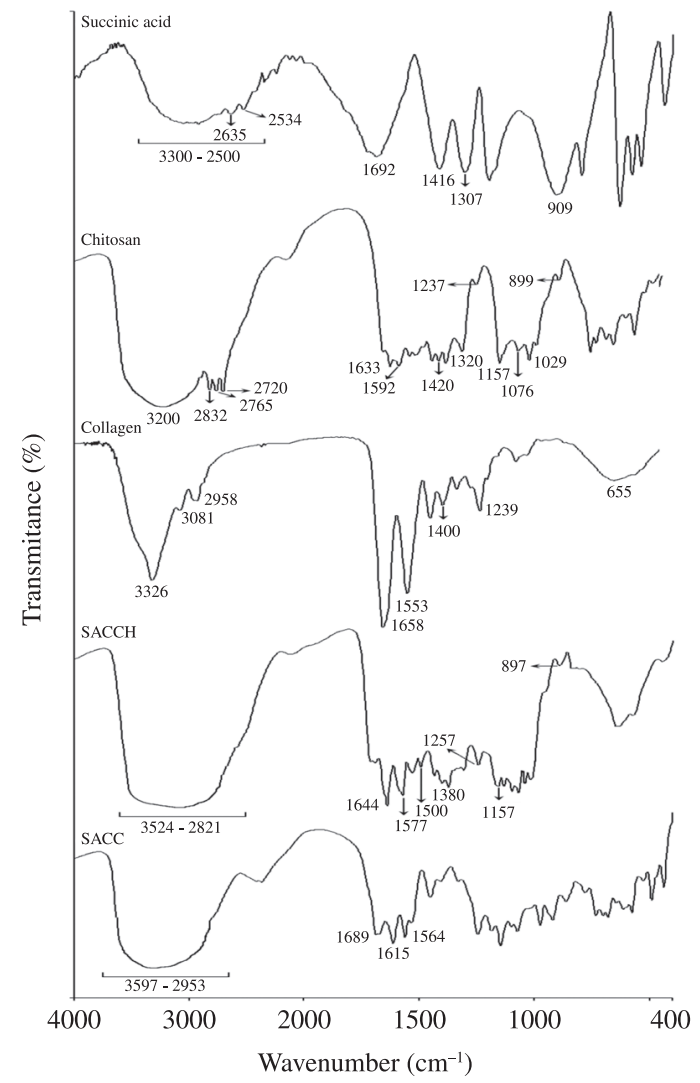

Figure 2. FT-IR spectrum of succinic acid (SA), Chitosan, type-I collagen, succinic acid cross-linked chitosan (SACCH) and succinic acid cross-linked collagen (SACC) scaffolds. 
Table 1. FT-IR analysis of succinic acid, chitosan and collagen ${ }^{31}$.

\begin{tabular}{|c|c|}
\hline Wavenumber $\left(\mathrm{cm}^{-1}\right)$ & Peak assignment \\
\hline \multicolumn{2}{|r|}{ Succinic acid } \\
\hline $3300-2500$ & Broad stretching vibration of $\mathrm{O}-\mathrm{H}$ group $\left(\mathrm{v}_{\mathrm{OH}}\right)$ \\
\hline 2635,2534 & $\mathrm{C}-\mathrm{H}$ stretching $\left(\mathrm{v}_{\mathrm{C}-\mathrm{H}}\right)$ \\
\hline 1692 & $-\mathrm{C}=\mathrm{O}$ group $\left(v_{\mathrm{C}=\mathrm{O}}\right)$ \\
\hline 1416 & $\mathrm{C}-\mathrm{O}-\mathrm{H}$ in-plane bending $\left(\delta_{\mathrm{C}-\mathrm{O}-\mathrm{H}}\right)$ \\
\hline 1307 & $\mathrm{C}-\mathrm{O}$ stretching vibration $\left(\mathrm{v}_{\mathrm{C}-\mathrm{O}}\right)$ \\
\hline 909 & Out- of- plane bending of the bonded $\mathrm{O}-\mathrm{H}\left(\delta_{\mathrm{O}-\mathrm{H}}\right)$ \\
\hline \multicolumn{2}{|r|}{ Chitosan } \\
\hline 3200 & $-\mathrm{NH}_{2}$ stretching vibration $\left(v_{\mathrm{NH}}\right)$ \\
\hline $2832,2765,2720$ & Symmetric or asymmetric $-\mathrm{CH}_{2}$ stretching vibration attributed to pyranose ring $\left(\mathrm{v}_{\mathrm{C}-\mathrm{H}}\right)$ \\
\hline 1633 & $-\mathrm{C}=\mathrm{O}$ in acetamide group (amide $\mathrm{I}$ band) \\
\hline 1592 & $-\mathrm{NH}_{2}$ bending vibration in amino group $\left(\delta_{\mathrm{NH}}\right)$ \\
\hline 1420,1320 & Vibrations of $\mathrm{OH}, \mathrm{CH}$ in the ring \\
\hline 1257 & $\mathrm{C}-\mathrm{O}$ group \\
\hline 1157 & $-\mathrm{C}-\mathrm{O}-\mathrm{C}$ in glycosidic linkage \\
\hline 1076,1029 & $\mathrm{C}-\mathrm{O}$ stretching in acetamide $\left(v_{\mathrm{C}-\mathrm{O}}\right)$ \\
\hline 899 & Corresponds to saccharide structure \\
\hline \multicolumn{2}{|r|}{ Collagen } \\
\hline 3326 & $-\mathrm{NH}_{2}$ stretching vibration $\left(v_{\mathrm{NH}}\right)$ \\
\hline 3081 & Fermi resonance overtone of 1553 band \\
\hline 2958 & $\mathrm{C}-\mathrm{H}$ stretching $\left(v_{\mathrm{C}-\mathrm{H}}\right)$ \\
\hline 1658 & Amide I band $\left(v_{C=0}\right)$ \\
\hline 1553 & Amide II band $\left(\delta_{\mathrm{NH}}\right)$ \\
\hline 1400 & Amide III band $\left(v_{\mathrm{C}-\mathrm{N}}\right)$ \\
\hline 1239 & $\mathrm{C}-\mathrm{N}$ stretching of amine $\left(\mathrm{v}_{\mathrm{C}-\mathrm{N}}\right)$ \\
\hline 655 & Out-of-plane N-H wagging of amide and amine $\left(\delta_{\mathrm{NH}}\right)$ \\
\hline
\end{tabular}

$v$-stretching, $\delta$ - bending.

In SACC spectrum, few changes were observed when compared to native type-I collagen this could be due to the cross-linking of type-I collagen with SA. A broad, strong absorption in the region of $3597-2953 \mathrm{~cm}^{-1}$ was resulting from superimposed $-\mathrm{OH}$ and $-\mathrm{NH}_{3}{ }^{+}$stretching band. In type-I collagen spectrum, a sharp intense amide-I band was observed around $1658 \mathrm{~cm}^{-1}$ which disappeared with the appearance of two new bands in 1689 and $1615 \mathrm{~cm}^{-1}$ in SACC spectrum and these bands were supposed to be caused by the $-\mathrm{NH}_{3}{ }^{+}$and $-\mathrm{COO}^{-}$respectively. Moreover, when compared with native type-I collagen spectrum, in SACC spectrum, there was a reduction in the region of $1564 \mathrm{~cm}^{-1}$ (overlapped band of amide II and free primary amines), which, may be due to the reduction of free $-\mathrm{NH}_{2}$ group in SACC. Results from FT-IR analysis reflected that SA was ionically cross-linked with chitosan and type-I collagen $^{30}$.

Though FT-IR analysis displayed the ionic interaction between the cross-linker and the natural polymers, results on the percentage of cross-linking degree suggested that increasing the concentration of succinic acid (up to $0.4 \%$ ) increases the degree of cross-linking and confirmed the interaction. Table 2 depicts the percentage of cross-linking degree of SACCH and SACC in the presence of increasing concentration of succinic acid. About $60-65 \%$ cross-linking was observed with $0.2 \%$ succinic acid with chitosan and collagen. However, in the case of experiments with
Table 2. Measurement of cross-linking degree of succinic acid cross-linked chitosan $(\mathrm{SACCH})$ and succinic acid cross-linked collagen (SACC) prepared using different concentrations of succinic acid $(0.05-0.5 \%)$

\begin{tabular}{ccc}
\hline $\begin{array}{c}\text { Concentration } \\
\text { of Succinic } \\
\text { acid }(\%, \mathbf{w} / \mathbf{v})\end{array}$ & $\begin{array}{c}\text { Percentage of cross- } \\
\text { linking degree of } \\
\text { SACCH }(\%) *\end{array}$ & $\begin{array}{c}\text { Percentage of cross- } \\
\text { linking degree of } \\
\text { SACC }(\%) *\end{array}$ \\
\hline 0.05 & $51 \pm 1$ & $53 \pm 2$ \\
0.1 & $57 \pm 1$ & $58 \pm 2$ \\
0.2 & $63 \pm 2$ & $65 \pm 1$ \\
0.3 & $72 \pm 1$ & $74 \pm 1$ \\
0.4 & $75 \pm 2$ & $78 \pm 1$ \\
0.5 & $75 \pm 2$ & $78 \pm 2$ \\
\hline
\end{tabular}

*mean $\pm \mathrm{SD}$ values.

glutaraldehyde, about $88-93 \%$ of cross-linking was observed with $0.2 \%$ concentration of glutaraldehyde.

With regard to mechanical property, a fundamental property for any scaffold in application point of view, results revealed that the mechanical strength of the scaffold was increased with an increase in succinic acid concentration up to $0.2 \%$. Further increase in SA concentration leads to decrease in mechanical strength (results not shown). Table 3 illustrates tensile strength, Young's modulus, stiffness of native and succinic acid $(0.2 \%)$ cross-linked scaffolds. 
High tensile strength $(\mathrm{MPa})$ values were observed for both the cross-linked scaffolds (SACCH- 0.92 and SACC- 2.25) compared to the native polymers (chitosan- 0.37 and type-I collagen - 0.13). Moreover, the Young's modulus of SACCH and SACC were calculated as 10.6 and 20.45 respectively. The stiffness values (SACCH- 2.91 and SACC- 0.97 N/mm) were also greater than that of the native biopolymers (chitosan- 0.79 and type-I collagen - $0.3 \mathrm{~N} / \mathrm{mm}$ ).

All these observations on mechanical properties suggested, succinic acid cross-linked scaffold materials demonstrated appreciable mechanical strength compared to glutaraldehyde cross-linked material, where, we observed brittleness. Schiffman et al. ${ }^{31}$ reported brittle nature of the biomaterial upon cross-linking with glutaraldehyde. Further, when the concentration of SA increased to $>0.2 \%$, a decrease in mechanical strength observed could be reasoned to a high degree of cross-linking of SA with the biopolymers and which is clearly proven from the results of TNBS assay ${ }^{32}$. In the same manner, with the high cross-linking degree, glutaraldehyde cross-linked scaffold displayed materials with brittle nature.

Glutaraldehyde could be covalently cross-linked with chitosan and collagen through the formation of the double bond $(\mathrm{C}=\mathrm{N}$, imine bond) between $-\mathrm{CHO}$ group of glutaraldehyde and $-\mathrm{NH}_{2}$ group of polymers (chitosan \& collagen), results with the large energy barrier for rotation of associated groups linked by a double bond $(\mathrm{C}=\mathrm{N})$ and finally provided brittle nature to the scaffold material.

Thermo gravimetric analysis for the experimental samples' SA, chitosan, type-I collagen, SACCH, SACC, GACCH and GACC were illustrated in Figure $3 a$, b and the corresponding thermal degradation values were displayed in Table 4. From the results, we observed that incorporation of succinic acid with chitosan and type-I collagen tends to shift the thermal region to higher temperature, and such a shift was attributed to an increase in thermal stability ${ }^{33}$.

Differential scanning calorimetry (DSC) studies performed to understand the behavior of SACCH and SACC on application of thermal energy suggested significant variation in the degradation temperatures for the test samples. Thermo grams of SA, chitosan, type-I collagen, SACCH, SACC, GACCH and GACC were shown in Figure 4a, b. Degradation temperature differences among SA $\left(189^{\circ} \mathrm{C}\right)$, chitosan $\left(108^{\circ} \mathrm{C}\right)$, type-I collagen $\left(92^{\circ} \mathrm{C}\right), \operatorname{SACCH}\left(132^{\circ} \mathrm{C}\right)$ and SACC $\left(123^{\circ} \mathrm{C}\right)$ was observed, whereas, for GACCH and GACC it was observed as 149 and $151^{\circ} \mathrm{C}$ respectively. The higher transition temperature suggested, $\mathrm{SACCH}$ and SACC have higher thermal stability and similar kind of observations was reported by Bhumkar et al. ${ }^{29}$.

Results on binding energy calculations based on the bioinformatics tool for the cross-linking of SA with chitosan and type-I collagen using Auto Dock software proved, chitosan and type-I collagen cross-linked with succinic

Table 3. Assessment of mechanical properties of chitosan, succinic acid cross-linked chitosan (SACCH), collagen and succinic acid cross-linked collagen (SACC) in terms of tensile strength, elongation at break, young's modulus and stiffness

\begin{tabular}{|c|c|c|c|c|c|c|}
\hline $\begin{array}{l}\text { Sample } \\
\text { Name }\end{array}$ & $\begin{array}{l}\operatorname{Maximum} \\
\operatorname{Load}(\mathbf{N})^{*}\end{array}$ & $\begin{array}{c}\text { Tensile } \\
\text { strength(MPa)* }\end{array}$ & $\begin{array}{c}\text { Elongation at } \\
\text { break }(\%)^{*}\end{array}$ & $\begin{array}{c}\text { Extension at } \\
\text { maximum load }(\mathbf{m m}) *\end{array}$ & $\begin{array}{c}\text { Young's Modulus/ } \\
\text { Tensile Modulus(MPa)* }\end{array}$ & $\begin{array}{l}\text { Stiffness }(\kappa) \\
(\mathrm{N} / \mathbf{m m})^{*}\end{array}$ \\
\hline Chitosan & $1.32 \pm 0.05$ & $0.37 \pm 0.02$ & $8.33 \pm 0.5$ & $1.67 \pm 0.5$ & $4.43 \pm 0.5$ & $0.79 \pm 0.02$ \\
\hline SACCH & $5.05 \pm 0.2$ & $0.92 \pm 0.02$ & $8.67 \pm 0.5$ & $1.73 \pm 0.5$ & $10.6 \pm 1.0$ & $2.91 \pm 0.5$ \\
\hline Collagen & $0.37 \pm 0.02$ & $0.13 \pm 0.02$ & $6.17 \pm 0.5$ & $1.23 \pm 0.04$ & $2.114 \pm 0.5$ & $0.3 \pm 0.01$ \\
\hline SACC & $2.14 \pm 0.05$ & $2.25 \pm 0.5$ & $22.00 \pm 1.0$ & $2.20 \pm 0.5$ & $20.45 \pm 1.5$ & $0.97 \pm 0.02$ \\
\hline
\end{tabular}

*mean \pm SD values.

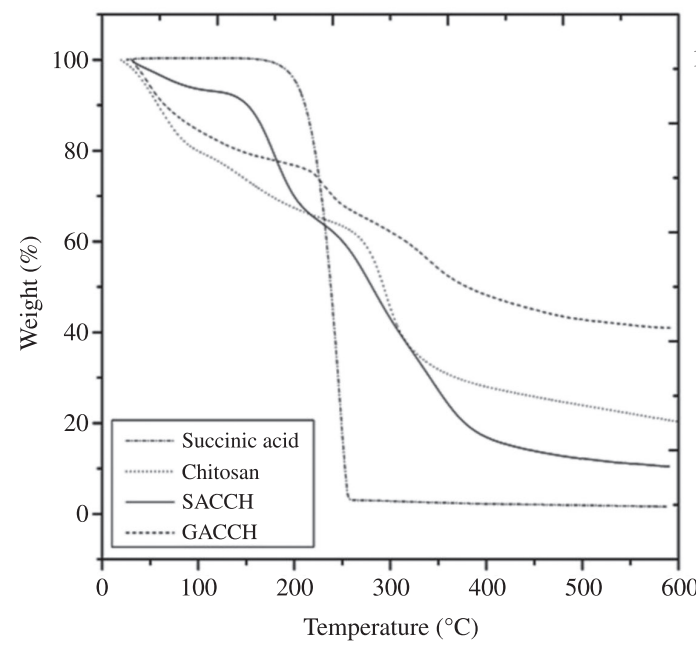

(a)

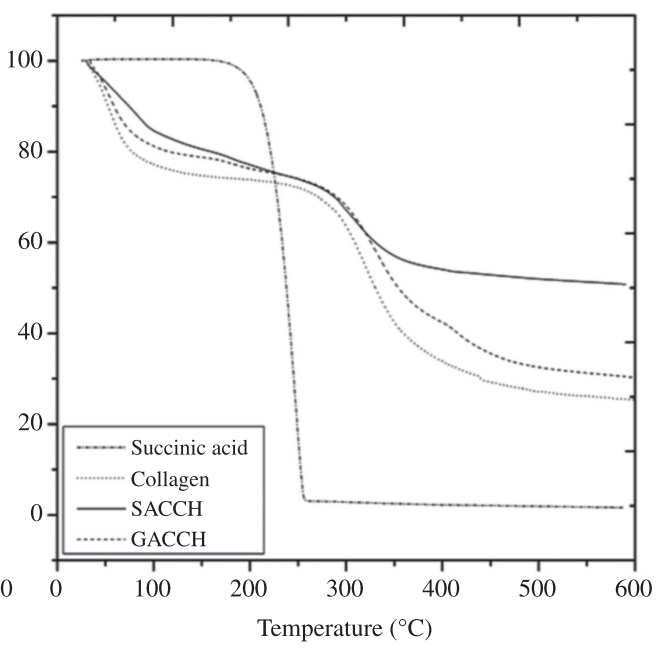

(b)

Figure 3. (a) Thermo gravimetric analysis (TGA) of Succinic acid (SA), Chitosan, succinic acid cross-linked chitosan (SACCH) and glutaraldehyde cross-linked chitosan (GACCH) scaffolds. (b) Thermo gravimetric analysis of Succinic acid (SA), collagen, succinic acid cross-linked collagen (SACC) and glutaraldehyde cross-linked collagen (GACC) scaffolds. 
acid not only through ionic interaction but also through multiple intermolecular hydrogen bondings. Autodock is an automated procedure for predicting the interaction of ligands with bio-macromolecular targets. Hundred runs were given for docking SA with chitosan and type-I collagen. The best binding energy values and their corresponding rank and run numbers were depicted in Table 5 . The binding energy of -4.53 and $-4.27(\mathrm{kcal} / \mathrm{mol})$ was observed when SA was interacted with chitosan and type-I collagen respectively. These interactions were made by multiple intermolecular hydrogen bonds between $-\mathrm{COOH}$ group of $\mathrm{SA}$ and $-\mathrm{NH}_{2}$ group of the chitosan and free $\varepsilon-\mathrm{NH}_{2}$ group of lysine from type-I collagen (Figure $5 \mathrm{a}, \mathrm{b}$ ). In addition to ionic crosslinking, hydrogen bonding interaction can also improve the mechanical property of the scaffold. The details of these intermolecular hydrogen bonding sites were given below.

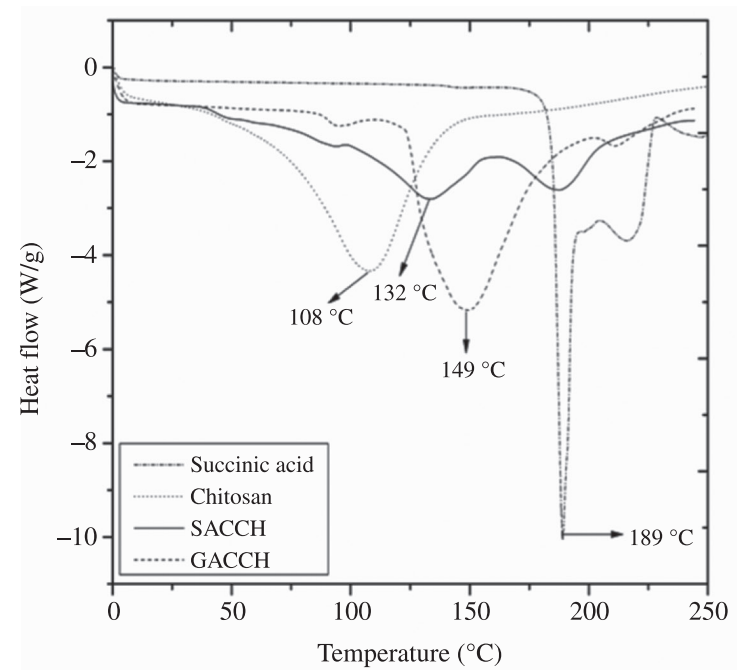

(a)

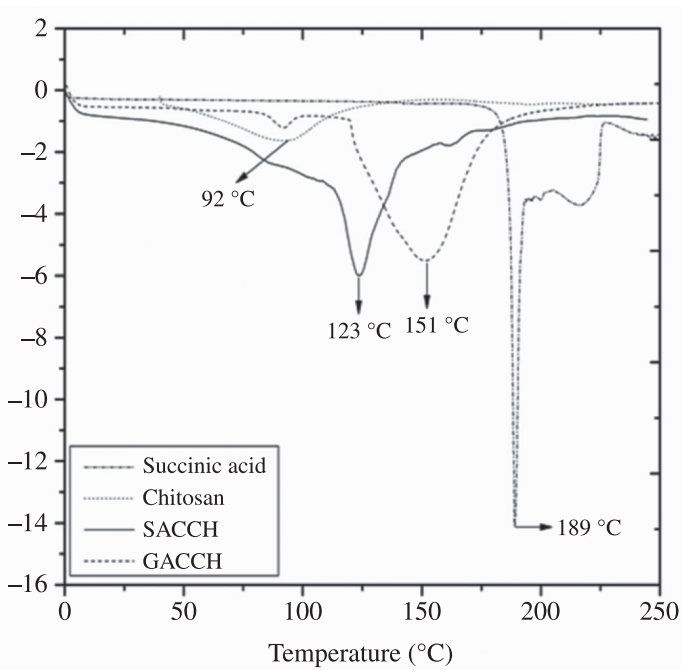

(b)

Figure 4. (a) Differential scanning calorimetry analysis of Succinic acid (SA), Chitosan, succinic acid cross-linked chitosan (SACCH) and glutaraldehyde cross-linked chitosan (GACCH) scaffolds. (b) Differential scanning calorimetry analysis of Succinic acid (SA), collagen, succinic acid cross-linked collagen (SACC) and glutaraldehyde cross-linked collagen (GACC) scaffolds.

Table 4. Thermal analysis of succinic acid (SA), chitosan, succinic acid cross-linked chitosan (SACCH), glutaraldehyde cross-linked chitosan $(\mathrm{GACCH})$, collagen, succinic acid cross-linked collagen (SACC) and glutaraldehyde cross-linked collagen (GACC) under $\mathrm{N}_{2}$ air atmosphere.

\begin{tabular}{cccccccc}
\hline \multirow{2}{*}{ Temperature $\left({ }^{\circ} \mathbf{C}\right)$} & \multicolumn{7}{c}{$\%$ weight loss (heating rate 20 ${ }^{\circ} \mathbf{C}$ min) } \\
\cline { 2 - 8 } & Succinic acid & Chitosan & SACCH & GACCH & Collagen & SACC & GACC \\
\hline 100 & 0 & 21 & 7 & 16 & 23 & 16 & 20 \\
200 & 4 & 33 & 31 & 24 & 27 & 23 & 24 \\
300 & 98 & 56 & 56 & 38 & 37 & 34 & 33 \\
400 & 98 & 73 & 84 & 52 & 67 & 46 & 58 \\
500 & 99 & 77 & 88 & 58 & 73 & 48 & 68 \\
600 & 99 & 81 & 90 & 60 & 75 & 50 & 70 \\
\hline
\end{tabular}

Table 5. Binding energy values of succinic acid cross-linked chitosan (SACCH) and succinic acid cross-linked collagen (SACC) scaffold.

The binding energy calculation between chitosan and Succinic acid based on autodock tool software.

\begin{tabular}{ccc}
\hline Rank & Binding energy $(\mathrm{Kcal} / \mathrm{mol})$ & No. of runs \\
1 & -4.53 & 74 \\
2 & -4.12 & 11 \\
3 & -4.04 & 53 \\
\hline
\end{tabular}

The binding energy calculation between type-I collagen and Succinic acid based on autodock tool software.

$\begin{array}{ccc}\text { Rank } & \text { Binding energy }(\mathrm{Kcal} / \mathrm{mol}) & \text { No. of run } \\ 1 & -4.27 & 13 \\ 2 & -4.16 & 35 \\ 3 & -3.60 & 44\end{array}$




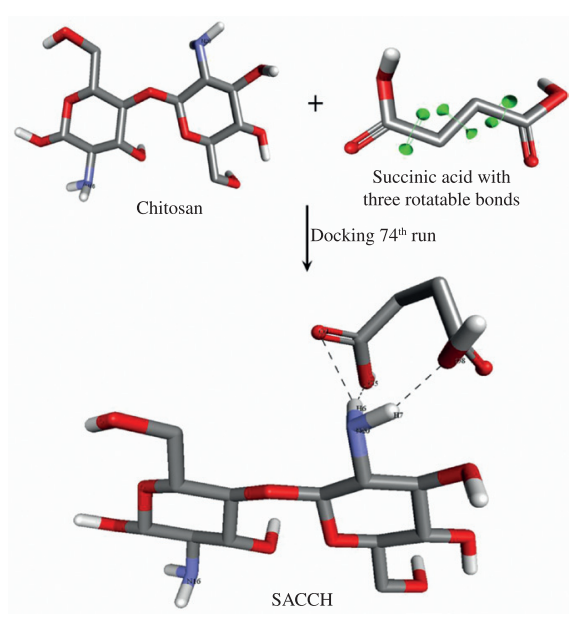

(a)

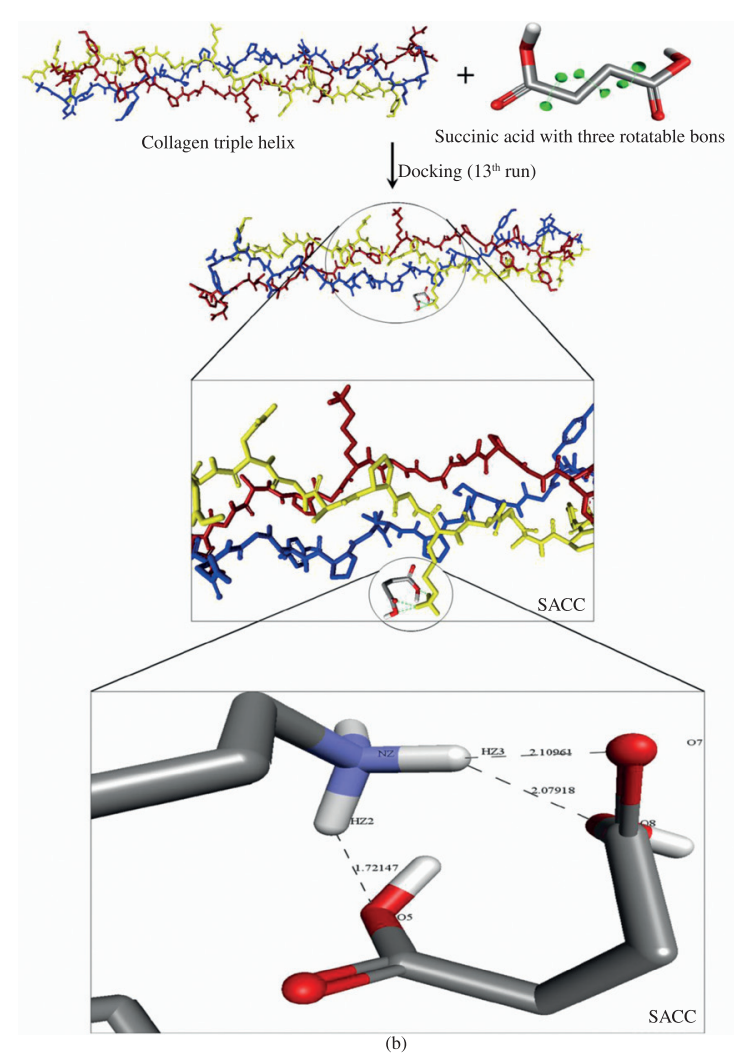

Figure 5. (a) Multiple hydrogen bonding interaction between chitosan and succinic acid (SA). (b) Multiple hydrogen bonding interaction between collagen and succinic acid (SA). (The black dotted line indicates the hydrogen bond. In figure white colour indicates hydrogen atom $(\mathrm{H})$, red indicates oxygen atom $(\mathrm{O})$, grey for carbon atom $(\mathrm{C})$ and blue corresponds to nitrogen atom $(\mathrm{N}))$.

\subsection{Intermolecular hydrogen bond details between SA and chitosan}

- H (6) of chitosan is linked with O (5) of SA with the bond distance of 1.70053 ;

- $\mathrm{H}$ (6) of chitosan is linked with O (4) of SA with the bond distance of 2.21416;

- H (7) of chitosan is linked with O (8) of SA with the bond distance of 1.64777 .

\subsection{Intermolecular hydrogen bond details between SA and type-I collagen}

(i) LYS (12) H2 of type-I collagen is linked with $\mathrm{O}$ (5) of SA with the bond distance of 1.72147 ;

(ii)LYS (12) H3 of type-I collagen is linked with $\mathrm{O}$ (7) of SA with the bond distance of 2.10961;

(iii) LYS (12) H3 of type-I collagen is linked with $\mathrm{O}$ (8) of SA with the bond distance of 2.07918, (H-Hydrogen, LYS- Lysine amino acid, O- Oxygen, SA- Succinic acid). 


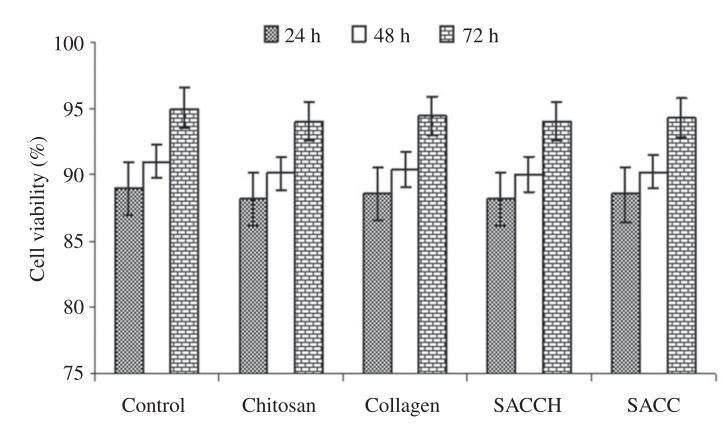

Figure 6. MTT analysis of control, chitosan, collagen, succinic acid cross-linked chitosan (SACCH) and succinic acid cross-linked collagen (SACC) scaffolds at 24, 48 and 72 hours time interval.
With reference to the biocompatibility of the resulting scaffold, cell attachment and cell viability assays were carried out. MTT assay was done to check the toxicity of the prepared scaffold (SACCH \& SACC). Only cells that are metabolically normal can turn the tetrazolium salts into purple crystals. Compared to native chitosan and type-I collagen, SACCH \& SACC showed no significant differences in absorbance (Figure 6), and suggested, scaffolds being in direct contact with fibroblast did not lead to apoptosis or necrosis. MTT results clearly indicated that NIH 3 T3 cells proliferated well on the surface of the SA cross-linked scaffolds (SACCH \& SACC). With regard to cell viability assay, we observed intense fluorescence of the cells on the surface of the native and cross-linked scaffold and suggested the viability of the cells as shown in Figure 7.
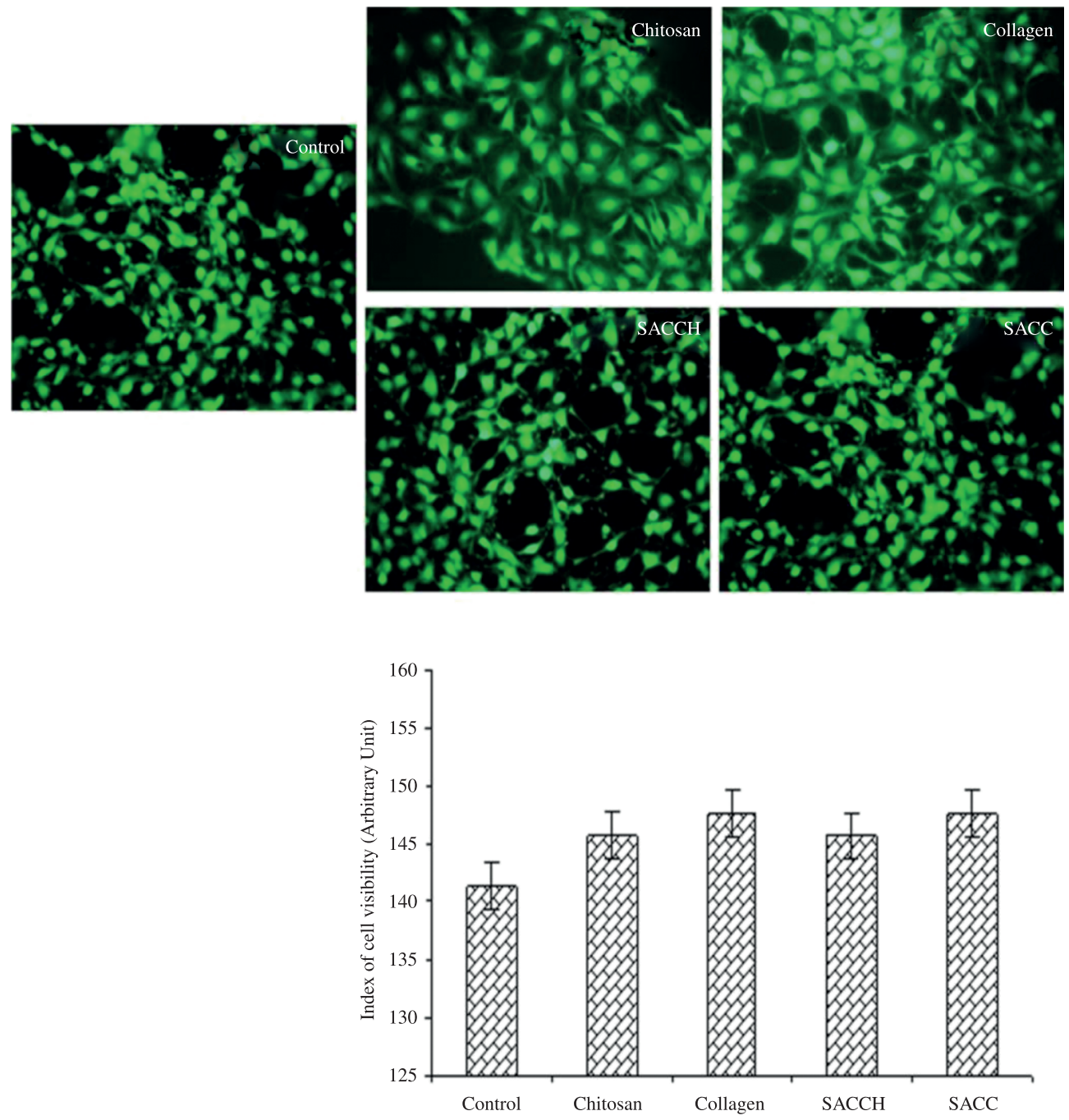

Figure 7. The upper part is the fluorescent cell images for the experimental samples, control, chitosan and collagen alone and succinic acid cross-linked chitosan $(\mathrm{SACCH})$ and succinic acid cross-linked collagen (SACC) and the lower part is the index of cell viability (arbitrary unit) assessed in SACCH (Succinic acid cross-linked chitosan) and SACC (Succinic acid cross-linked collagen) scaffold in comparison with the parent molecules and control. (The assay was carried out using cell tracker kit. NIH3T3 Cells were treated on the surface of native and cross-linked scaffolds for 6 hours followed by incubation with cell viable dye cell tracker for 30 minutes. Fluorescence images of the cells were acquired by DP71 camera adapted to an Olympus IX71 microscope. Intensity of green positive cells were counted and plotted. Fluorescence intensities of the images were calculated using Adobe Photoshop version 7.0). 


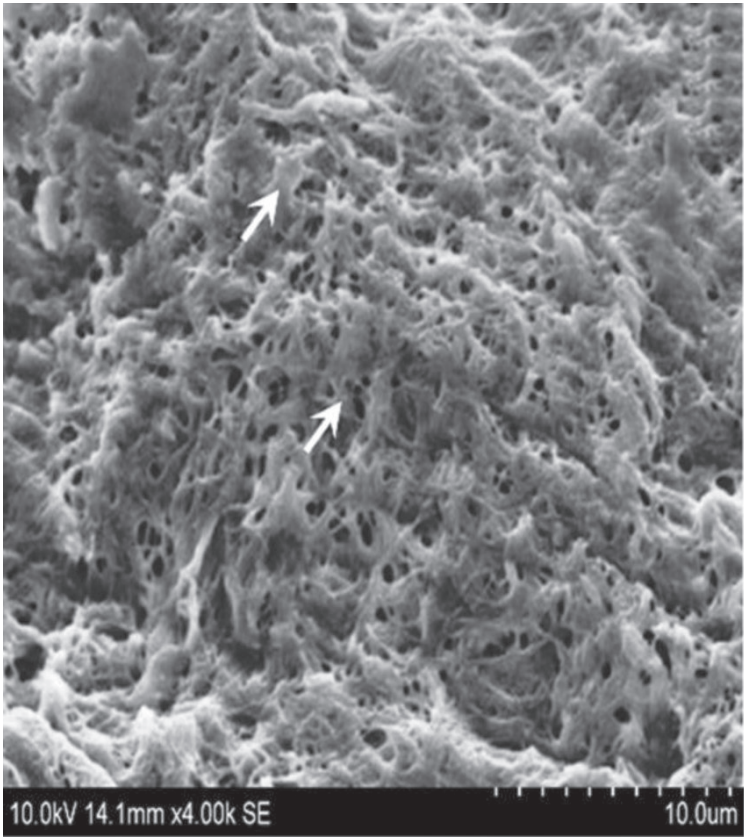

(a)

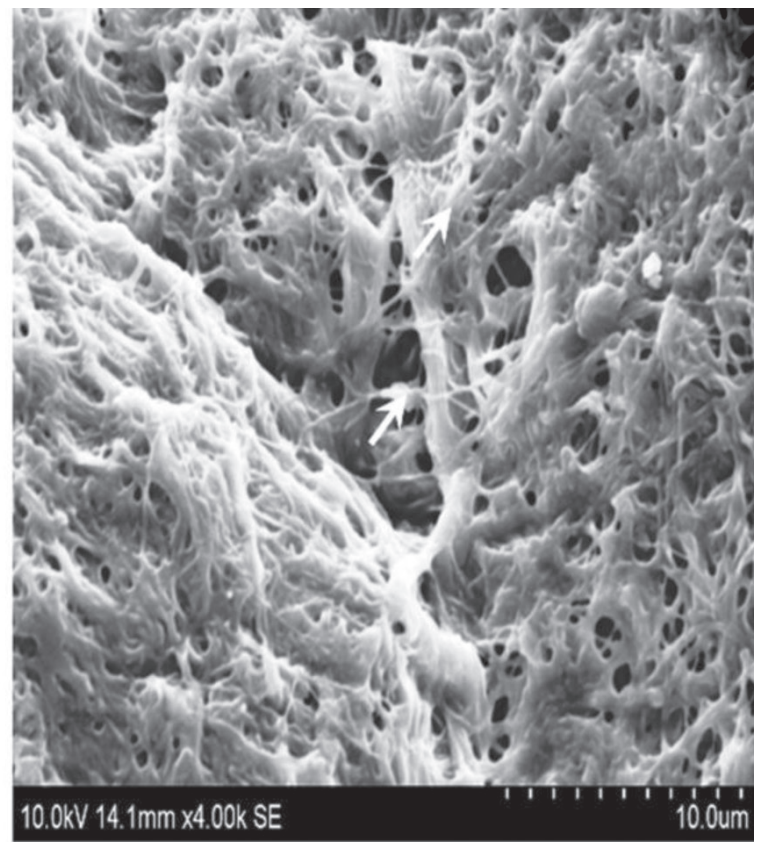

(b)

Figure 8. (a) Attachment of fibroblast cells on the SACCH scaffold after being cultured for prolonged time (12 days). White arrow indicates the adhered cells on the scaffold. (b) Attachment of fibroblast cells on the SACC scaffold after being cultured for prolonged time (12 days). Porous SACC scaffold was completely covered by fibroblast cells, which are indicated by white colour arrow marks.

SEM images of the horizontally sectioned cell seeded SACCH \& SACC scaffold displayed in Figure 8a, b demonstrated that after being cultured for prolonged time (12 days), fibroblasts were detected in the scaffold (SACCH \& SACC) with typical spindle-shaped morphology and suggests that the cells were infiltrated and proliferated in the scaffolds.

\section{Conclusion}

The present study explicitly demonstrates that succinic acid acts as suitable cross-linker for the preparation of biocompatible scaffold from chitosan \&collagen with appreciable mechanical properties. The interaction of succinic acid with chitosan and collagen was identified as non-covalent interactions, i.e., both ionic and multiple intermolecular hydrogen bonding interactions. All the instrumental analyses and bioinformatics tool authenticated

\section{References}

1. Hashimoto K, Sudo M, Sugimura T and Inagaki Y. Synthesis of novel block copolymers containing polyamide4 segments and control of their biodegradability. Journal of Applied Polymer Science. 2004; 92(6):3492-3498. http://dx.doi.org/10.1002/ app. 20348

2. Liu Y, Guo LK, Huang L and Deng XM. Preparation and Properties of a Biodegradable Polymer as a Novel Drug Delivery System. Journal of Applied Polymer Science. 2003; 90(11):31503156. http://dx.doi.org/10.1002/app.13061

3. Engelmayr GC, Hildebrand DK, Sutherland FWH, Mayerand JE and Sacks MS. A novel bioreactor for the dynamic flexural the non-covalent interactions. The scaffold prepared upon cross-linking of succinic acid with chitosan and collagen was the green method of preparation. Succinic acid not only solubilizing the chitosan and collagen in water but also improves the property of the scaffold through its noncovalent cross-linking interaction with chitosan and collagen. No toxic compounds were involved in this preparation and the resultant scaffold found application as wound dressing material or as an implant in clinical applications.

\section{Acknowledgements}

One of the authors Mr. Tapas Mitra acknowledges CSIR, New Delhi for the financial assistance provided in the form of CSIR-SRF. All the authors thank Dr. Swaraj Sinha and Dr. Suvro Chatterjee, Au-KBC research centre, MIT Campus, Anna University, Chennai for their help and lab facility to perform cell lines studies.

stimulation of tissue engineered heart valve biomaterials. Biomaterials. 2003; 24(14):2523-2532. http://dx.doi.org/10.1016/ S0142-9612(03)00051-6

4. Ligler FS, Lingerfelt BM, Price RP and Schoen PE. Development of uniform chitosan thin-film layers on silicon chips. Langmuir. 2001; 17(16):5082-5084. http://dx.doi. org/10.1021/la010148b

5. Schauer CL, Chen MS, Chatterley M, Eisemann K, Welsh ER and Price RR. Color changes in chitosan and poly (allyl amine) films upon metal binding. Thin Solid Films. 2003; 434(1-2):250-257. http://dx.doi.org/10.1016/S0040-6090(03)00055-5

6. Jin J, Song M and Hourston DJ. Chitosan-Based Films Cross-Linked by Genipin with improved Physical Properties. 
Biomacromolecules. 2004; 5(1):162-168. PMid:14715022. http://dx.doi.org/10.1021/bm034286m

7. Tual C, Espuche E, Escoubes $\mathrm{M}$ and Domard AJ. Transport properties of chitosan membranes: influence of crosslinking. Journal of Polymer Science Part B: Polymer Physics. 2000; 38(11):1521-1529. http://dx.doi. org/10.1002/(SICI)1099-0488(20000601)38:11<1521::AIDPOLB120>3.0.CO;2-\#

8. Usha R and Ramasami T. Effect of crosslinking agents (basic chromium sulfate and formaldehyde) on the thermal and thermomechanical stability of rat tail tendon type-I collagen fibre. Thermochim Acta. 2000; 356(1-2):59-66. http://dx.doi. org/10.1016/S0040-6031(00)00518-9

9. Sheu MT, Huang JC, Yeh GC and Ho HO. Characterization of type-I collagen gel solutions and type-I collagen matrices for cell culture. Biomaterials. 2001; 22(13):1713-1719. http:// dx.doi.org/10.1016/S0142-9612(00)00315-X

10. Miles CA, Avery NC, Rodin VV and Bailey AJ. The increase in denaturation temperature following cross-linking of type-I collagen is caused by dehydration of the fibres. Journal of Molecular Biology. 2005; 346(2):551-556. PMid:15670603. http://dx.doi.org/10.1016/j.jmb.2004.12.001

11. Nam K, Kimura $\mathrm{T}$ and Kishida A. Controlling coupling reaction of EDC and NHS for preparation of type-I collagen gels using ethanol/water co-solvents. Macromolecular Bioscience. 2008; 8(1):32-37. PMid:18023082. http://dx.doi. org/10.1002/mabi.200700206

12. Song TY, Yao C and Li XS. Electrospinning of zein/chitosan composite fibrous membranes. Chinese Journal of Polymer Science. 2010; 28(2):171-179. http://dx.doi.org/10.1007/ s10118-010-8239-2

13. Saito H, Murabayashi S, Mitamura $Y$ and Taguchi T. Characterization of alkali-treated type-I collagen gels prepared by different crosslinkers. Journal Materials Science: Materials in Medicine. 2008; 19(3):1297-1305. PMid:17851737. http:// dx.doi.org/10.1007/s10856-007-3239-7

14. Charulatha $V$ and Rajaram $A$. Influence of different crosslinking treatments on the physical properties of collagen membranes. Biomaterials. 2003; 24(5):759-767. http://dx.doi.org/10.1016/ S0142-9612(02)00412-X

15. Leung HW, Ecotoxicology of glutaraldehyde: review of environmental fate and effects studies. Ecotoxicology and Environmental Safety. 2001; 49(1):26-39. PMid:11386713. http://dx.doi.org/10.1006/eesa.2000.2031

16. Ballantyne B and Jordan SL. Toxicological, medical and industrial hygiene aspects of glutaraldehyde with particular reference to its biocidal use in cold sterilization procedures. Journal of applied toxicology. 2001; 21(2):131-151. PMid:11288136. http://dx.doi.org/10.1002/jat.741

17. Horn HJ, Holland EG and Hazleton LW. Food additives, safety of adipic acid as compares with citric and tartaric acid. Journal of Agricultural and Food Chemistry. 1957; 5(10):759-762. http://dx.doi.org/10.1021/jf60080a007

18. Mitra T, Sailakshmi G, Gnanamani A, Raja ST, Thiruselvi T, Mangala Gowri V et al. Preparation and characterization of a thermostable and biodegradable biopolymers using natural cross-linker. International Journal of Biological Macromolecules. 2011; 48(2):276-285. PMid:21126533. http:// dx.doi.org/10.1016/j.ijbiomac.2010.11.011

19. Peng L, Cheng XR, Wang JW, Xu DX and Wang GE. Scaffolds for Periodontal Tissue Engineering. Journal of Bioactive and
Compatible Polymers. 2006; 21(2):207-220. http://dx.doi. org/10.1177/0883911506065100

20. Bubnis WA and Ofner CM. The determination of $\varepsilon$-amino groups in soluble and poorly soluble proteinaceous materials by a spectrophotometric method using trinitrobenzenesulfonic acid. Analytical Biochemistry. 1992; 207(1):129-133. http:// dx.doi.org/10.1016/0003-2697(92)90513-7

21. Advanced Chemistry Development - ACD. ChemSketch. version 12. Toronto: ACD Inc.; 2009.

22. University of California. Creating Collagen Models. Gencollagen. Available from: <http://www.cgl.ucsf.edu./cgibin/gencollagen.py>.

23. Morris GM, Huey R, Lindstrom W, Sanner MF, Belew RK and Goodsell DS. Autodock4 and AutoDockTools4: automated docking with selective receptor flexibility. Journal of Computational Chemistry. 2009; 30(16):2785-2791. PMid:19399780 PMCid:2760638. http://dx.doi.org/10.1002/ jcc. 21256

24. Trentani L, Pelillo F, Pavesi FC, Ceciliani L, Cetta G and Forlino A. Evaluation of the $\mathrm{TiMo}_{12} \mathrm{Zr}_{6} \mathrm{Fe}_{2}$ alloy for orthopaedic implants: in vitro biocompatibility study by using primary human fibroblasts and osteoblasts. Biomaterials. 2002; 23(14):2863-2869. http://dx.doi. org/10.1016/S0142-9612(01)00413-6

25. Mossmann T. Rapid colorimetric assay for cellular growth and survival: application to proliferation and cytotoxicity assays. Journal of Immunological Methods. 1983; 65(1-2):55-63. http:// dx.doi.org/10.1016/0022-1759(83)90303-4

26. Majumder S, Siamwala JH, Srinivasan S, Sinha S, Sridhara SRC, Soundararajan G et al. Simulated Microgravity Promoted Differentiation of Bipotential Murine Oval Liver Stem Cells by Modulating BMP4/Notch1 Signaling. Journal of Cellular Biochemistry. 2011; 112(7):1898-1908. PMid:21433062. http:// dx.doi.org/10.1002/jcb.23110

27. Ohkawa K, Cha DI, Kim H, Nishida A and Yamamoto H. Electrospinning of chitosan. Macromolecular Rapid Communication. 2004; 25(18):1600-1605. http://dx.doi. org/10.1002/marc.200400253

28. El-Tahlawy K, Gaffar MA and El-Rafie S. Novel method for preparation of cyclodextrin/grafted chitosan and its application. Carbohydrate Polymers. 2006; 63(3):385-392. http://dx.doi. org/10.1016/j.carbpol.2005.08.057

29. Bhumkar DR and Pokharkar VB. Studies on effect of $\mathrm{pH}$ on crosslinking of chitosan with sodium tripolyphosphate: a technical note. Journal of the American Association of Pharmaceutical Scientists. 2006; 7(2):1-6.

30. Pavia DL, Lampman GM and Kriz GS. Introduction to Spectroscopy. 3rd ed. Thomson Learning, Inc.; 2001.

31. Schiffman JD, Schauer CL. Cross-linking chitosan nanofibers. Biomacromolecules. 2007; 8(2):594-601. PMid:17291083. http://dx.doi.org/10.1021/bm060804s

32. Wang Y, Ameer GA, Sheppard BJ and Langer R. A tough biodegradable elastomer. Nature Biotechnology. 2002; 20: 60206. PMid:12042865. http://dx.doi.org/10.1038/nbt0602-602

33. Nunes PS, Bezerra M S, Costa LP, Cardoso J C Albuquerque Junior RLC, Rodrigues MO et al. Thermal characterization of usnic acid/collagen-based films. Journal of Thermal Analysis and Calorimetry. 2010; 99:1011-1014. http://dx.doi. org/10.1007/s10973-009-0661-8 